\title{
Paisaje de fondo o paisaje pleno: los paisajes y jardines del Madrid galdosiano
}

\author{
María Jesús Martín Sánchez *
}

\begin{abstract}
RESUMEN
Pérez Galdós fue uno de los más prolíficos escritores de la literatura española del siglo XIX. Puede ser considerado como cronista debido a su atención especial por el detalle

y su observador punto de vista. Nuestro escritor llegó a Madrid y vivió aquí desde 1862 hasta 1920, y recogió todos los cambios que sufrió nuestra ciudad a lo largo del siglo. La obra de Galdós nos muestra todos los paisajes y ambientes, y es un importante documento para conocer cómo vivían nuestros antepasados, cuales eran sus preferencias, lo que les gustaba y lo que no. Uno de los puntos más interesantes de esta ciudad son los jardines; $y$, sobre todo, los jardines como signo de ascenso social. Así, podemos encontrar diferentes modelos que son repetidos por las clases pudientes: el paisajista y el geométrico son los dos más

importantes. Tener salud, gracias a un medio natural, es lo que todos buscaban paseando por jardines públicos, yendo a las fiestas de sociedad en las maravillosas estufas de los jardines privados, 0 intentando imitarlas comprando plantas
\end{abstract}

\section{ABSTRACT}

Pérez Galdós was one of the most prolific writers of 19th century Spanish Literature. He can be considered as a cronicler because of his attention to detail and observant point of view. Our writer arrived to Madrid and lived here from 1862 to 1920 , and collected all the changes our city suffered through the century. Galdós' work shows us every landscape and ambient, and it's a very important document to know how our ancestors lived, their preferences, likes and dislikes. One of the most interesting points of this city are the gardens; and above all, gardens as sign of social promotion. So we can find very different kind of models which are repeated by each well-to-do class: landscaping and geometric gardens were the two most important of them. Being healthy, thanks to a natural enviroment, is what everybody looks for, walking along public parks, going to social parties in marvelous greenhouses built in private gardens, or trying to imitate them buying plants in order to decorate their homes.

* Tercer Ciclo. Departamento de Historia del Arte. UNED. 
para decorar las casas. También es importante la enorme diferencia entre el paisaje en el que vive la gente rica y el de

los pobres; el primero es exuberante, agradable y lleno de plantas, pero el otro es seco y triste. Uno aparece como paisaje de fondo y el otro como paisaje pleno.
Also it's very important the huge difference between the landscape where rich people lives and the poor's; the first one is exhuberant, pleasant and plenty of plants, but the other is dry and sad. One appears asa background landscape, and the last one asa full landscape.

A lo largo del siglo XIX, como consecuencia de la recuperación de la naturaleza que propugnan corrientes literarias y filosóficas nacidas en el siglo XVII y desarrolladas en el XVIII, aumenta el interés por el cuidado de las zonas verdes. Sus efectos beneficiosos para la salud eran un elemento necesario para la higiene de la ciudad, ya que funcionaban como pulmón en un momento en que las ciudades crecen y es preciso buscar un desahogo; esto ocurrirá muy especialmente a partir de la segunda mitad de esa centuria y serán lugares de paseos y citas. Este interés se ve especialmente reflejado en las actuaciones de las clases privilegiadas, bien sea la monarquía, la nobleza o la nueva burguesía, aspecto que podemos ver recogido en la obra de cronistas, urbanistas y escritores como Don Benito Pérez Galdós. Los personajes galdosianos aparecen en paisajes que, en ocasiones, nos dicen mucho más de ellos que sus propias palabras. Se nos habla así de los cambios que sufren las ciudades en las que viven, qué gustos imperan y cuales son sus deseos.

Fue a partir del Romanticismo, cuando el paisaje aparece en el arte de una manera autónoma ${ }^{1}$, sin necesidad de tener un tema del cual ser fondo. En ese momento, la naturaleza está ahí y el artista elige lo que quiere representar de ella, concepto que se asentará con el Realismo y el Naturalismo. Pero los primeros testimonios de emoción estética frente a la belleza del entorno natural fueron las artes poéticas, aunque sea la pintura la disciplina más apta para plasmar este sentimiento. Al igual que un pintor selecciona un marco natural para plasmarlo en un lienzo mediante colores y líneas, el escritor lo hace por medio de palabras. Es la pintura de las palabras.

La relación del arte con la literatura, en especial con la pintura - como el ya clásico «Ut pictura poesis"- se ha de hacer extensivo al resto de las disciplinas artísticas. En numerosas ocasiones, al leer las páginas de un libro, nos encontramos con unos pasajes que se nos clavan en la retina a

1 Ayala, F. "El paisaje y la invención de la realidad", en Paisaje, juego y multilingüismo, Actas del X Simposio de la Sociedad Española de Literatura General y Comparada. Universidad de Santiago de Compostela. Santiago de Compostela, 18-21 octubre de 1994. Pág. 24. 
modo de "cuadros", y que los retenemos como imágenes vividas por nosotros mismos; son paisajes, unas partes de un espacio geográfico que el autor privilegia, recoge y nos transmite mediante retazos descriptivos, que enlazan los unos con los otros, y que la mayoría de las veces aparecen como marcos de una historia, donde la sitúa, y los personajes toman conciencia de su situación o clase social, etc... Galdós recoge cada uno de los aspectos y elementos del paisaje madrileño, y lo transmite con gran exactitud; no en vano puede ser considerado como cronista, y será para el Madrid decimonónico, junto a Mesonero Romanos - como lo fuera Lope de Vega en el siglo XVII y Ramón Gómez de la Serna en el XX- el literato que mejor nos describe la capital.

Galdós era un voraz paseante de ciudades; las retenía en su cabeza y, como un excelente dibujante, las plasma luego en papel, afición que vuelca en sus obras como podemos ver en algunos de sus pasajes: "Qué magnífico sería abarcar en un sólo momento toda la perspectiva de las calles de Madrid (...)" "2. Así descubrimos los aspectos más cambiantes de la ciudad entre los que sin ninguna duda se encuentran los jardines y zonas ajardinadas. Pero el límite temporal del Madrid galdosiano no se limita a los casi sesenta años que vivió en esta ciudad - desde 1860 a 1920 cuando murió - sino que se extiende a un tiempo anterior al momento de su llegada, a principios del XIX. Sin ir más lejos, los célebres Episodios Nacionales comienzan con el reinado de Carlos IV.

La ciudad que recoge la pluma del escritor canario es la morada de una aristocracia decadente que poco a poco va abandonando sus viejos palacios situados en el centro de la urbe, una burguesía que va residir en el nuevo barrio de Salamanca y una clase media-baja que fue ocupando zonas de nueva urbanización como Chamartín, Argüelles, etc. ${ }^{3}$

Para llevar a cabo esta crónica madrileña, nuestro escritor recurrió a la descripción de dos tipos de paisaje: el paisaje de fondo, y el paisaje pleno. El primero es un paisaje que encuadra las escenas y en el que los personajes se relacionan con la ciudad y entre sí, mientras que al referirme al segundo tipo hablo del paisaje puro, de los verdaderos "cuadros", de instantáneas de unos paisajes en los que los personajes aparecen como un elemento más del mismo. Gracias a estos retazos veremos cómo evolucionan en Madrid uno de los aspectos urbanísticos más cambiantes.

2 ShOemaker, W.H. Los artículos de Galdós en La Nación, 1865-6, 1868, Insula, Madrid, 1972, págs. 189-90, citado por ORTIz ARMENGOL, P. en «El urbanismo madrileño y su evolución históricosocial», en Madrid en Galdós, Galdós en Madrid, Catálogo de la exposición en el Palacio de Cristal, mayo de 1998, C.A.M., Madrid, 1988, pág. 71.

3 ORTIz ARMENGoL, P. «El urbanismo madrileño...», op. cit., pág. 76. 


\section{EL PAISAJE PLENO}

Don Benito utiliza todo tipo de recursos para mostrarnos esos paisajes puros, y en ocasiones echa mano de todo su bagaje cultural y plasma no sólo lo que ve, sino que también crea paisajes nacidos en su imaginación. Así nos encontraremos, algunas veces, ante unos «paisajes homéricos», siguiendo el modelo del locus amoenus ${ }^{4}$, lugares bucólicos, propios de escenas de amor y de la tradición más clásica de los paisajistas, pero que ya deja entrever esas notas propias del paisaje noventaiochista ${ }^{5}$ recogiendo un paisaje árido, propio de los interiores castellanos; como en uno de los pasajes de Tristana, en que nos describe los lugares apartados que buscan para pasear la protagonista y su novio, un artista que terminará olvidándola.

«Algunas tardes, paseando junto al canalillo del Oeste, ondulada tira de oasis que ciñe los áridos contornos del terruño madrileño, se recreaban en la placidez bucólica de aquel vallecito en miniatura (...) el remolino de hojas caídas, que el viento barría suavemente amontonándolas junto a los tron$\cos ;(. .$.$) el ligero temblor de las más altas ramas de los árboles... " 6$.

Si bien la descripción más clara de un paisaje realista con rasgos noventaiochistas lo encontramos en Misericordia, cuando habla del Arrabal de las Cambroneras, durante un paseo de la protagonista, Benina.

«...a la margen izquierda del Manzanares, en terreno bajo, (...). Encontrose en una como plazoleta (...)donde nacen silvestres espinos, cardos y raquíticas yerbas. El sitio es pintoresco, ventilado, y casi se puede decir alegre, porque en él dominan las verdes márgenes del río, los lavaderos ${ }^{7}$ y los tenderijos de trapos de mil colores" ${ }^{8}$.

A lo largo de la obra galdosiana encontramos varias alusiones a este tipo de paisaje que, por lo general, se identifica con los lugares donde residen o pasean los protagonistas del estrato social más bajo, y que los mismos personajes nos dicen que «no es bello; es majo" "; porque

- GuILléN, C., cita a Ernst Robert Curitus cuando reconoce una cita de Libanio (siglo IV), donde se resumen los deleites del locus amoenus, en «El hombre invisible: paisaje y literatura en el siglo XIX», artículo que aparece en Paisaje, juego y multilingüismo, ob. cit., pág. 71 .

Para el estudio de la relación entre la pintura y la Generación del 98 ver el libro de Carmen Pena Pintura de paisaje e ideología: la generación de 98, Ed. Taurus, Madrid, 1982.

6 Pérez Galdós, B. Tristana, Alianza Editorial, Madrid, 1984, pág. 55.

Es interesante destacar que es en estos momentos cuando Aureliano Beruete pinta en sus cuadros los lavaderos del Manzanares.

8 Pérez Galdós, B. Misericordia, Cátedra, Madrid, 1993, pág. 225.

9 Pérez Galdós, B. España trágica, Episodios Nacionales, Serie Final nº 42, Editorial Caja Madrid, Madrid, 1996, pág. 161. 
veremos que el paisaje bello es el que rodea a las clases adineradas. La diferencia entre los dos paisajes madrileños, el brillante de las clases adineradas y el más árido de los madrileños más humildes, la encontramos en un pasaje con una alusión muy clara al paisaje noventaiochista:

«estaba al noroeste, mirando, por un lado, al Madrid flamante, poblado de casas alegres y de frescos jardines; $y$, por otro, a las vastas soledades polvorientas (...). Desde la parte oriental del hotel se veía aquel triste paisaje de lomas manchegas... ${ }^{10}$.

La alusión más clara a ese paisaje bucólico clásico la hace en Misericordia, cuando Almudena, compañero de miserias de Benina, nos habla de su tierra, como contraposición a la aridez de la tierra en la que ahora vive y nos cuenta que «...ser yo nacido en un pueblo mu bunito que Ilaman allá Ullah de Bergel, terra, de Sus...jOh! terra divina, bunita...mochas arbolas, aceita, miela, flores, támalas, mocha güena..." ". Esta cita es muy interesante porque remite a la idea de jardín como reproducción del Paraíso ${ }^{12}$, ya que nos está hablando del «vergel de Aláh» ${ }^{13}$, algo, por otra parte, muy ligado a la tradición del jardín musulmán, y que se repite a lo largo de la historia de la jardinística. Es una de las alusiones que tienen como referente el «locus amoenus», si bien se trata del oriental y no el occidental, que se identifica más con verdes campiñas que con plantas exóticas como las támaras, o palmeras datileras, y que curiosamente abundan también en Canarias, región de donde es oriundo nuestro escritor. Tal vez, se trate de una proyección de los sentimientos del autor, comparando el paisaje canario con la aridez castellana, o un reflejo del gusto de la época por las plantas exóticas que se llevará incluso a exposiciones ${ }^{14}$.

Galdós hará otras alusiones a los jardines del Paraíso, de paisaje celestial fruto ya de su imaginación que parece un anticipo de pintura sim-

10 Pérez Galdós, B. La familia de León Roch, Ed. Aguilar, Madrid, 1975, pág. 833.

11 Pérez Galdós, B. Misericordia, ob. cit., pág. 145.

12 El paraíso musulmán tiene «un esquema estético claro: jardín con sombra de árboles y arbustos perfumados», y de aguas que fluyen, «jardín escenario de amor, libaciones y manjares, jardín de estética sensorial», como recoge María Jesús Ruibera Mata en su artículo «El jardín transcendido o el jardín árabe medieval», recogido en Jardines y Paisajes en el Arte y la Historia, dirigido por Carmen Añón, Ed. Complutense, Madrid, 1995, pág. 13.

${ }_{13}$ Es interesante la relación de la cita con la idea de Paraíso musulmán, que viene directamente de las palabras de Aláh en el Corán; así la referencia al paraíso, es siempre una referencia al “coránico». Francisco PÁEz de la Cadena recoge este aspecto en Historia de los estilos en jardinería, cap. 4, «El paraíso en la tierra», Ed. Itsmo, Madrid, 1982, págs. 61-94.

14 El gusto por las plantas exóticas llevará a la proliferación de construcciones peculiares como son las estufas, y también hace alusión a ellas Galdós en varios pasajes de sus obras que recojo más adelante. 
bolista $o$, incluso, mágico por lo que tiene de onírico, y que nada tiene que ver con la descripción del paraíso musulmán:

«Pasaron de improviso a un campo abierto y luminoso. Veían un suelo azul, arbolitos del mismo color, de tronco rígido, follaje recortado, formando algunos copa esférica, otros cónica, sin proyectar sombra en el suelo" ${ }^{15}$.

Pero no será el paisaje pleno el que más interese a don Benito, ya que nos lo muestra como ambientación de escenas más que como motivo principal y objeto de descripción.

\section{PAISAJES DE FONDO}

Son lugares de encuentro para los personajes; la ciudad que nuestro escritor describe, a través de las relaciones humanas, no es un mero decorado, sino un elemento que se va transformando, como lo hacen los demás personajes, con los que está íntimamente relacionado. Estos paisajes de fondo se identifican con los diferentes ambientes sociales madrileños, y en ocasiones aparecen como lugares de cierta relevancia histórica. Pero la mayoría de las veces son lugares de citas amorosas, de encumbramiento o identificación social.

De todos ellos el que aparece en más ocasiones es El Retiro, que en su día fuera Real Sitio y que pasó a ser lugar público en la centuria pasada. A través de las obras de don Benito podemos hacer una reconstrucción de las diferentes etapas por las que transcurrió tan emblemático parque, ya que fue testigo y marco de numerosos hechos históricos. Vemos así un primer Retiro, Real Posesión, aunque en claro declive, durante el reinado de Carlos IV, que sentía una clara preferencia por otros Reales Sitios - que también aparecen recogidos en esta amplísima obra literaria-. En este momento El Retiro era uno de los límites de Madrid ${ }^{16}$, desde donde entraron las tropas francesas ${ }^{17}$, y donde tuvieron lugar los fusilamientos ${ }^{18}$. Más adelante se trasforma en lugar de

15 Pérez Galdós, B. España trágica, op. cit., pág. 24.

16 Pérez Galdós, B. El Equipaje del Rey José, Episodios Nacionales, Serie Segunda, $n^{0} 11$, Ed. Historia 16, Madrid, 1993, pág. 23. Aquí aparece como lugar de entrada a Madrid.

17 Para estudiar la ocupación de El Retiro por las tropas francesas ver los trabajos de TOAJAS LÓPEZ, M. «Archivo del Palacio Real. Documentos del Buen Retiro II. Ocupación del Buen Retiro por los franceses", en Reales Sitios, n 52, 1977, págs. 57-62, y «Archivo del Palacio Real. Documentos del Buen Retiro Ill. La destrucción del Real Sitio, en Reales Sitios, n 53, págs. 12-16.

18 Pérez Galdós, B. El 19 de Marzo y el 2 de Mayo, Episodios Nacionales, Serie Primera, $n^{\circ}$ 3, Ed. Historia 16-Caja Madrid, Madrid, 1992, págs. 220-221. 
reunión y solaz de todos los ciudadanos madrileños, adquiriendo un aspecto muy similar al actual.

Tras el destrozo sufrido por la invasión de las tropas francesas e inglesas y con la vuelta de Fernando VII, EI Retiro será objeto de algunas transformaciones. Para complacer a su esposa, Isabel de Braganza desencantada ante la barbarie y el estado deplorable ${ }^{19}$ en el que quedaron las posesiones de la Corona-, el Rey decide acometer la transformación en zona de recreo para la Familia Real. A comienzos del siglo XIX impera la moda surgida en Inglaterra del "jardín paisajista", que reproduce, en estudiados, escenarios las infinitas variaciones ofrecidas por la naturaleza, tomándose como elementos decorativos todo tipo de árboles, arbustos, variadas especies florales, estanques, riachuelos, colinas artificiales, rocallas, palacetes fantásticos, kioskos, y toda una serie de imaginativas obras que contribuyen a crear ambientes misteriosos, evocando otras civilizaciones. Y, como era natural, Fernando VII no iba a substraerse a esta moda, y encarga a Isidro González Velázquez la reforma de los jardines de El Retiro inspirándose en estas tendencias. La intención era devolver al Real Sitio su anterior esplendor, algo que al parecer se consiguió, según cronistas como Mesonero Romanos ${ }^{20}$, pero para ello se hicieron enormes gastos ${ }^{21}$, como ya ocurrió en el siglo anterior. Los madrileños consideraron los cambios como la octava maravilla ${ }^{22}$, en especial la parte que el Rey eligió para sí y su familia, que recibió el nombre de «Reservado» y que se pobló de construcciones ${ }^{23}$, caprichosas novedades que a los ojos de Fernández de los Ríos eran ridículos y de mal gusto, calificándolos de «juguetes sin gracia» ${ }^{24}$. De la misma opinión debía ser don Benito, o al menos eso parece en uno de los pasajes de La de Bringas, cuando habla de esas construcciones de la zona exclusiva de la Corona, ya que la protagonista por ser una trabajadora de Palacio podía acceder a esta zona.

19 Alcalá Galiano, A., recoge, en Recuerdos de un anciano, t.VIII, 1890, Madrid, pág. 93, una descripción del aspecto en que quedó esta Real Posesión.

${ }_{20}$ Mesonero Romanos, R. de El Antiguo Madrid. Paseos histórico-anecdóticos por las calles y las casas de esta villa, Madrid, 1861, pág. 322.

21 MADOZ, P. «Madrid, audiencia, provincia, intendencia, vicaría, partido y villa», Diccionario geográfico-estadístico-histórico de España y sus posesiones de Ultramar, (Madrid, 1848), Ed. Giner, Madrid, 1981, pág. 394.

${ }_{22}$ Mesonero Romanos, R. de Memorias de un setentón, vol. II, Clásicos madrileños, Ed. Castalia, Madrid, 1994, pág. 254.

${ }^{23}$ Así se siguió la moda iniciada en Europa por $\mathrm{M}^{\mathrm{a}}$ - Antonieta cuando encargó la construcción de una aldea en el Petit Trianon de París, cfr. ARIza Muñoz, C. en «La jardinería en los Reales Sitios en el Madrid fernandino», en Reales Sitios, $n^{\circ} 90,1986$, pág. 90.

${ }_{24}$ Fernández de los Rios, A. Guía de Madrid, Madrid, 1876, ed. facsímil Abaco, pág. 395. 
"Y cuánto gozaban viendo la Casita del Pobre, la del Contrabandista y la Persa, echando migas a los patitos de la Casa del Pescador, subiendo por las espirales de la Montaña artificial, que es el colmo del artificio. Todos aquellos regios caprichos, así como la Casa de las Fieras, declaran la época de Fernando VII, que si en política fue brutalidad, en Artes fue tontería pura.» ${ }^{25}$.

Mesonero Romanos también compartía esta opinión debido al enorme despilfarro que supuso llevar a cabo estos deseos y caprichos regios ${ }^{26}$.

Si la cita anterior es interesante porque supone, además de la exposición de una opinión de don Benito acerca de las construcciones del Reservado, la enumeración de las mismas, hay otro fragmento, esta vez en La Desheredada, donde uno de los protagonistas nos indica la gran variedad de especies - algunas de ellas de singular rareza ${ }^{27}$-, que recogía la Casa de las Fieras ${ }^{28}$, una de las mayores atracciones de la época y heredera de construcciones semejantes de monarcas anteriores.

Pero mientras existía esa zona dedicada en exclusiva a la Familia Real, el resto de las posesiones fueron abiertas al público en general, que acudía allí a pasear, a correr y sentirse liberados, como le ocurre a Isadora, protagonista de La desheredada. En su paseo por el Parque del Retiro se despertaron en ella sus instintos más naturales, de correr por el «bosque civilizado", ya que aquel "ambiente, compuesto de frescura y tibieza, al mismo tiempo atemperaba el cuerpo y el alma» ${ }^{29}$. La idea de dar saludables paseos por el parque se repite contínuamente en la obra de Galdós y es algo que hacen los representantes de todas las clases sociales, si bien serán las más acomodadas las que lo realicen con más asiduidad. También acudía allí en coche «el Madrid elegante y almibarado (...)escaparate vivo (...)aquel cuya vida está cifrada en la presunción, en la coquetería." ${ }^{30}$. Además, don Benito repite esta idea en la mayoría de sus obras: las clases más adineradas acuden a presumir a la que fue Posesión Real, algo que no gustaba al pueblo llano, ya que El Retiro era de todos los ciudadanos, en especial a partir de su cesión al Ayuntamiento de Madrid tras la revolución de 1868, momento en que su «lindo nombre han querido en

25 Pérez Galdós, B. La de Bringas, ed. Hernando, Madrid, 19980, págs. 89-90.

26 Mesonero Romanos, R. de. «Los Jardines del Retiro» (1840), en Escenas matritenses por el Curioso Parlante, Madrid, edición de Fernando Plaza del Amo, 1991, pág. 688, donde habla de estas construcciones como «magníficas superfluidades, producto de «puerilidad de ideas".

27 Mesoneros Romanos, R. de. Manual de Madrid, Madrid, 1844, pág. 402.

2s Pérez Galdós, B. La desheredada, Alianza, Madrid, 1995, pág. 71.

29 PÉREZ Galdós, B. La desheredada, también en Obras Completas, Novelas, ed, Aguilar, Madrid, 1975, pág. 1007.

30 Péfez Galdós, B. Recuerdos y memorias, ed. Tebas, Madrid, 1975, pág. 36. 


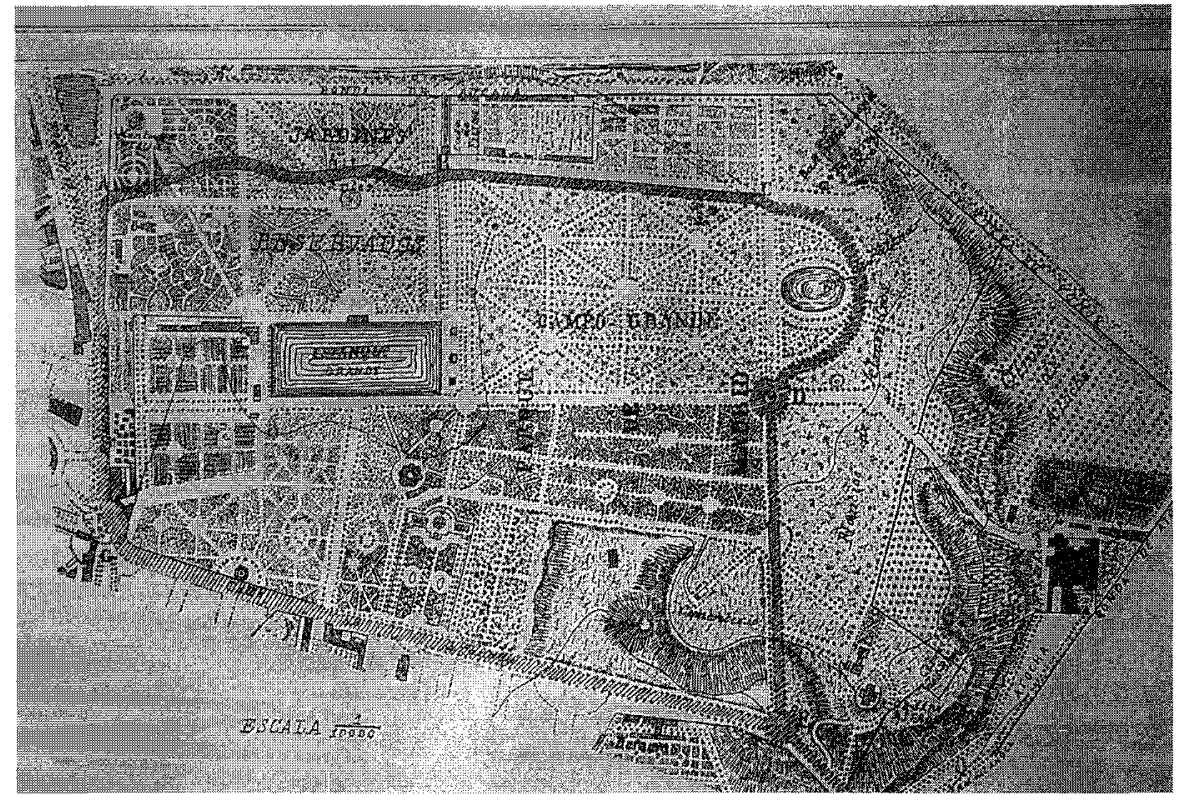

Fig.1. Plano del Parque de Madrid con la vía proyectada para carruajes. (La llustración Española y Americana, 1874).

vano cambiase por el insulso rótulo de «Parque de Madrid» ${ }^{31}$. Muy significativo es el siguiente fragmento, que nos dice mucho más de lo que debía ser entonces pasear por este popular parque:

«Allá va un coche..., y otro, y otro. Tomá, aquel es el Ministro(...) ¡Cuánto habrá robado ese hombre para llevar cocheros con tanto galón! (...) ¿de dónde han sacado tanto encaje? (...) El Retiro es muy bonito, sólo que ..., de aquellas cosas que pasan, habiendo tantos que tienen frío, el pueblo debería venir aquí a cortar leña... Entro por este paseo de los muñecos de piedra con las manos y las narices rotas. ¡Qué feos son!...». ${ }^{32}$

En este pasaje se hace alusión al Paseo de las Estatuas, o de Argentina, que ya aparece trazado en el siglo XVII, pero que fue abierto por la reina Isabel II, y del que aún disfrutamos actualmente. En este paseo se colocaron como motivo ornamental doce estatuas, seis a cada lado, sobre simples pedestales, que representaban a diversos reyes de

31 Ibidem.

32 Pérez Galdós, B. La desheredada, op. cit., págs. 422-4. 
España. Fueron encargadas casi un siglo antes por Isabel de Farnesio para ser ubicadas en las cornisas del Palacio Real, pero se colocaron allí con poca coherencia cronológica. Pedro Antonio de Alarcón describía este paseo como una «extensa calle de árboles, con magnífica perspectiva, adornada de colosales estatuas, encerrada en el laberinto de bosques y jardines» ${ }^{33}$.

El lugar de El Retiro preferido por los madrileños adinerados era el Paseo de Coches, donde acudían "dándose un pisto estrepitoso" ${ }^{34}$, y a lucir sus mejores galas, como hemos visto en la cita anterior. Alli acudían "con insulsed metódica»" ${ }^{35}$, todos los días y a la misma hora. Pero la apertura de este paseo ${ }^{36}$, el 23 de octubre de 1874, fue polémica y se consideró, por parte de un gran sector de la sociedad, como una desgracia ${ }^{37}$, ya que se tuvieron que talar gran cantidad de árboles y el césped fue sustituído por una carretera, lo cual supuso un paso más en la destrucción del parque como pulmón de la ciudad y desencadenó una serie de denuncias plasmadas en artículos como el de Ramón Molinos. Este autor hacía una defensa acalorada de los grandes espacios por donde poder pasearse bajo los árboles, que ayudaran a conservar en Madrid la poca frescura que le queda ${ }^{38}$.

Pero esta destrucción comenzó bastante antes, y don Benito liga el declive del parque con el de la Monarquía, en especial a partir de la venta de terrenos del Retiro que hizo la reina Isabel II, y sobre lo que existe un fragmento muy interesante en La de Bringas, que nos habla de un paseo de Rosalía y Pez por esa zona:

«Iban saliendo por la puerta de la Glorieta. Ya estaban descuajadas las famosas alamedas de castaños de indias, quitada la verja y puestos a la venta los terrenos, operación que se llamó rasgo. Esta palabra fue muy funesta para la Monarquía, árbol a quién no le valió ser más antiguo que los castaños, porque también lo descuajaron e hicieron leña de él.» ${ }^{39}$.

Esta acción acometida por la Reina tuvo muchos detractores, pero dio lugar a un nuevo barrio, el comprendido entre las calles Alcalá y Alfonso

33 Alarcón, P.A. de. Museo Universal II, 30-5-1858, nº 10, pág. 75.

${ }_{34}$ PÉrez Galdós, B. Misericordia, op. cit., pág. 127-8.

35 Pérez Galdós, B. La familia de León Roch, op.cit., pág. 814.

${ }^{36}$ La obra fue iniciativa del duque de FERNÁN NúÑEZ, que aportó para ello una gran suma de dinero, según se recoge en un articulo firmado con las iniciales J.M.A., «Se abre al público el paseo de coches del Retiro", en Crónica de Madrid, ed. Plaza y Janés-Diario 16, Madrid, 1991, pág.285.

${ }_{37}$ Fernández de los Ríos, A. op. cit., págs. 367 y 369.

3s Molinos, R. «Defensa acalorada del Retiro», en Crónica de Madrid, op. cit., pág. 320.

39 Pérez Galdós, B. La de Bringas, op. cit., pág.94. 


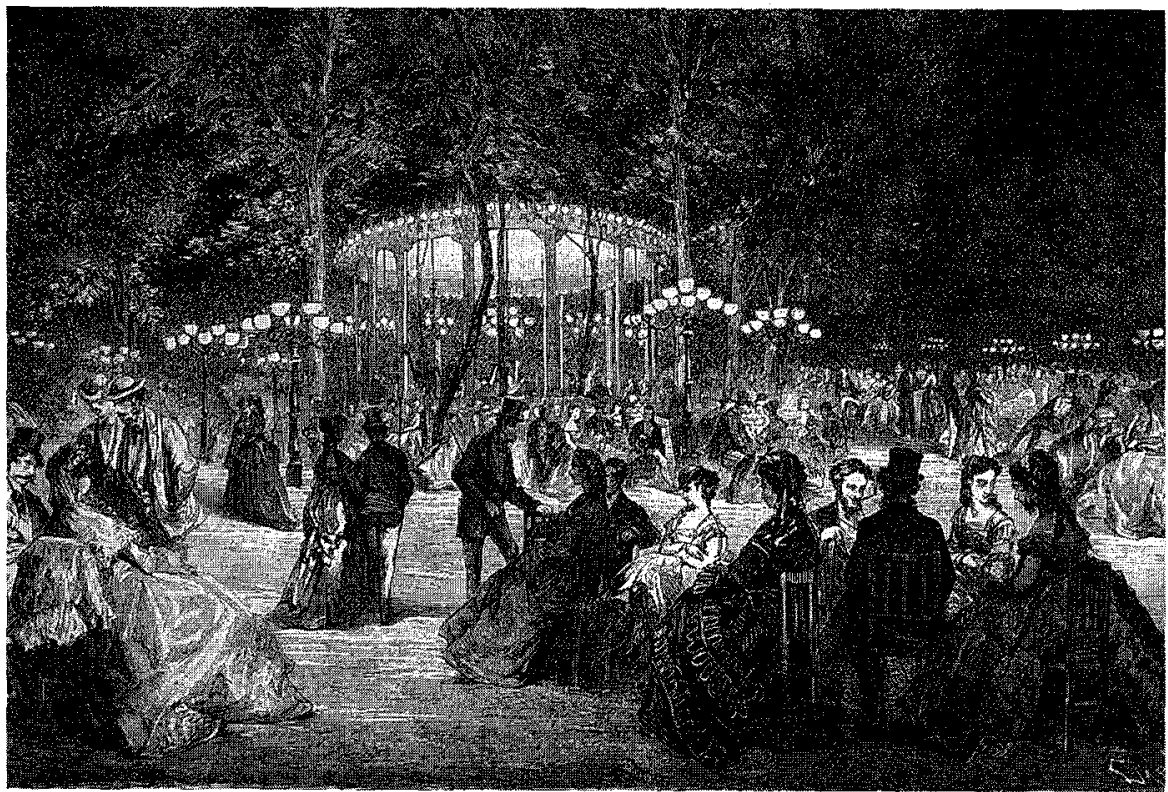

Fig. 2. Concierto en el Jardín del Buen Retiro.

(La llustración Española y Americana, 1870).

XII, Jardín Botánico y Paseo del Prado, dedicado a las clases acomodadas, de antiguo o nuevo cuño. Su creación se recoge también en El amigo Manso, obra cuya acción tiene lugar en 1877, cuando se habla de la nueva casa, "hermosa finca, allá en los holgados barrios próximos al Retiro" ${ }^{40}$, que se compra doña Javiera, una carnicera enriquecida, que tiene un hijo que tal vez algún día se emparente con la aristocracia, y que ofrece una habitación al protagonista con unas maravillosas vistas al parque madrileño ${ }^{41}$. En otro barrio vecino, en la calle Claudio Coello, se encuentra también la casa de Vicente Halconero, protagonista de La España trágica, y desde su balcón se ve el Retiro, incluso parte del estanque ${ }^{42}$.

El siguiente paso en detrimento del Retiro fue su cesión, tras la Gloriosa, mediante un decreto, al Ayuntamiento de Madrid. El artículo pri-

\footnotetext{
40 Pérez Galdós, B. El amigo Manso, en Obras Completas, ed. Aguilar, Madrid, 1975, pág. 1.284 .

41 «...Asomémonos. Estas si que son vistas. Cuando usted tenga la cabeza pesada de tanto estudiar, se asoma al mirador y se traga con los ojos el Retiro", PÉREz GALDÓs, B. El amigo Manso, Alianza, Madrid, 1980, pág. 248.

42 Pérez Galdós, B. La España Trágica, op. cit. pág. 153.
} 
mero decía que «El Gobierno Provisional cede para Parque de Madrid el Sitio del Buen Retiro en toda su extensión. El Ayuntamiento de Madrid deberá respetar sus límites actuales y destinarlo exclusivamente al recreo del vecindario de esta capital». De este modo la capital de España contaría con un parque como lo hacían las grandes ciudades europeas, donde el pueblo acudía como lugar de recreo, instrucción, higiene y moralidad, algo que ya propuso Mesonero Romanos en 1836, para que se convirtiese en una «mansión de placer que no tuviera nada que envidiar a los parques más célebres, ni al Wauxal de Londres", disponiendo de diversas huertas de producción, jardines de aclimatación, bosques, teatros, dioramas, etc ${ }^{43}$. Y la comparación del Retiro con esos otros jardines europeos la recoge Galdós en Fortunata y Jacinta, cuando uno de sus personajes, Moreno Isla, confunde nuestro parque con otro que existe en Inglaterra, donde habitó varios años, ya que aún conserva muchas de las costumbres de allí: «... a las doce de un hermoso día de octubre, regresaba a casa de vuelta de un paseíto por Hide Park..., digo por el Retiro.» ${ }^{44}$.

Y siguiendo la función principal que debía tener este parque se organizaron numerosos actos que tenían la finalidad el servir de entretenimiento a los habitantes de Madrid. Don Benito también hace referencia a estos actos y fiestas alli celebrados:

«Nos dijo que el tiempo estaba magnífico y, enseñándonos billetes de invitación para no sé qué fiesta de caridad que había en los Jardines del Retiro, nos animó a que fuéramos» ${ }^{45}$.

Pero, además, se mejoraron las construcciones existentes y se hicieron otras nuevas, y allí se instalaron numerosos cafés, restaurantes, etc, donde los madrileños acudían frecuentemente, en especial en el buen tiempo ${ }^{46}$. Los miércoles y los sábados por la noche tenían lugar conciertos de Arbau, Botessini, Barbieri o Dalmau, y la "concurrencia era de lo más principal» ${ }^{47}$. Algo de lo que nos habla uno de los personajes galdosianos que nos comenta que "...en público, francamente, no se puede prescindir de ciertas

\footnotetext{
43 Mesonero Romanos, R. de. "El Buen Retiro", en el Semanario Pintoresco español, 8 mayo 1836, no 6 , pág. 52 .

44 Pérez Galdós, B. Fortunata y Jacinta, Cátedra, Madrid, 1983, pág. 331.

45 Pérez Galdós, B. El amigo Manso, op. cit., pág. 183.

45 Pérez Galdos, B. Lo prohibido, Clásicos Castalia, Madrid, 1971, pág. 259. Donde José María Bueno propone a su enamorada Camila ir «a un Restaurant, al Retiro..., donde gustes. Está un día delicioso».

${ }_{47}$ MetaberRy, A. "Los jardines del Retiro», en Madrid por dentro y por fuera: guía de forasteros incautos, Asociación de libreros de Lance, Madrid, 1996, pág. 258.
} 
cosas. (...) Además, ¿qué persona que se estime no va al teatro tres o cuatro veces por semana, al circo y a los conciertos del Retiro en verano?...” ${ }^{48}$.

De este parque recoge también los puntos que más populares eran, como fuentes y estanques. Respecto a las primeras tendremos que remontarnos de nuevo al reinado de Fernando VII ya que fue él el que las dotó de un mejor caudal ${ }^{49}$. De ellas, las que más veces se menciona es la peculiar Fuente Egipcia ${ }^{50}$, que la gente llamó «la Tripona», y que aún se conserva aunque bastante deteriorada. También es interesante destacar la alusión que se hace a los estanques como elementos distintivos del parque. Uno de ellos es el Estanque de las Campanillas, donde los suicidas acudían porque era un sitio recóndito y poco transitado. Sobre esto nos escribe Galdós cuando uno de sus personajes comenta que a Madrid sólo le falta tener mar para arrojarse cuando acaba la esperanza, y como alternativa su hija le habla de los estanques del Retiro ${ }^{51}$. En Fortunata y Jacinta se habla de un artículo de periódico en el que se menciona el asesinato de un hombre que es arrojado al estanque por su esposa ${ }^{52}$. También se hace alusión a un intento de suicidio en el estanque "chinesco» en Rosalía ${ }^{53}$.

El Retiro es el jardín que más veces aparece como paisaje de fondo, pero don Benito retrata otros de cierta relevancia que podíamos llamar «privados», entre los que se encuentran los que también son o han sido propiedad de la Corona.

A finales del siglo XVIII, ya asentada y establecida la dinastía borbónica en España, Madrid como asiento de Corte pasa por un momento de esplendor. Un pequeño cinturón de villas suburbanas, reales o pertenecientes a la nobleza formaban un anillo alrededor de la ciudad. Hay que recordar que el jardín era casi un juego de sociedad y que la corriente escenográfica que inundó Europa a finales del siglo XVIII llegará con retraso a nuestro país, tamizado por el filtro francés, con las características propias del clima español y la esencia de la tradición italiana. Para hablar de

48 Pérez Galdós, B. Rosalía, Cátedra, Madrid, 1983, pág. 155.

49 Gómez lglesias, A. «El Buen Retiro», en Villa de Madrid, nº 24, 1968, pág. 38

so Hay varias alusiones a esta fuente, donde se acudía a beber agua. Cabe destacar:

- Pérez Galdós, B. La de Bringas, op. cit., pág.89.

- Pérez Galdós, B. Cánovas, Episodios Nacionales, Serie fínal, nº 46, ed. Ha 16-Caja Madrid, Madrid, 1990, pág. 69.

51 Pérez Galdós, B. Siete de Julio, Episodios Nacionales, Serie segunda, n 15, editorial Alianza-Hernando, Madrid, 1976, pág. 49.

52 Pérez Galdós, B. Fortunata y Jacinta, op. cit., pág. 280.

53 Pérez Galdós, B. Rosalía, op. cit., pág. 240. 


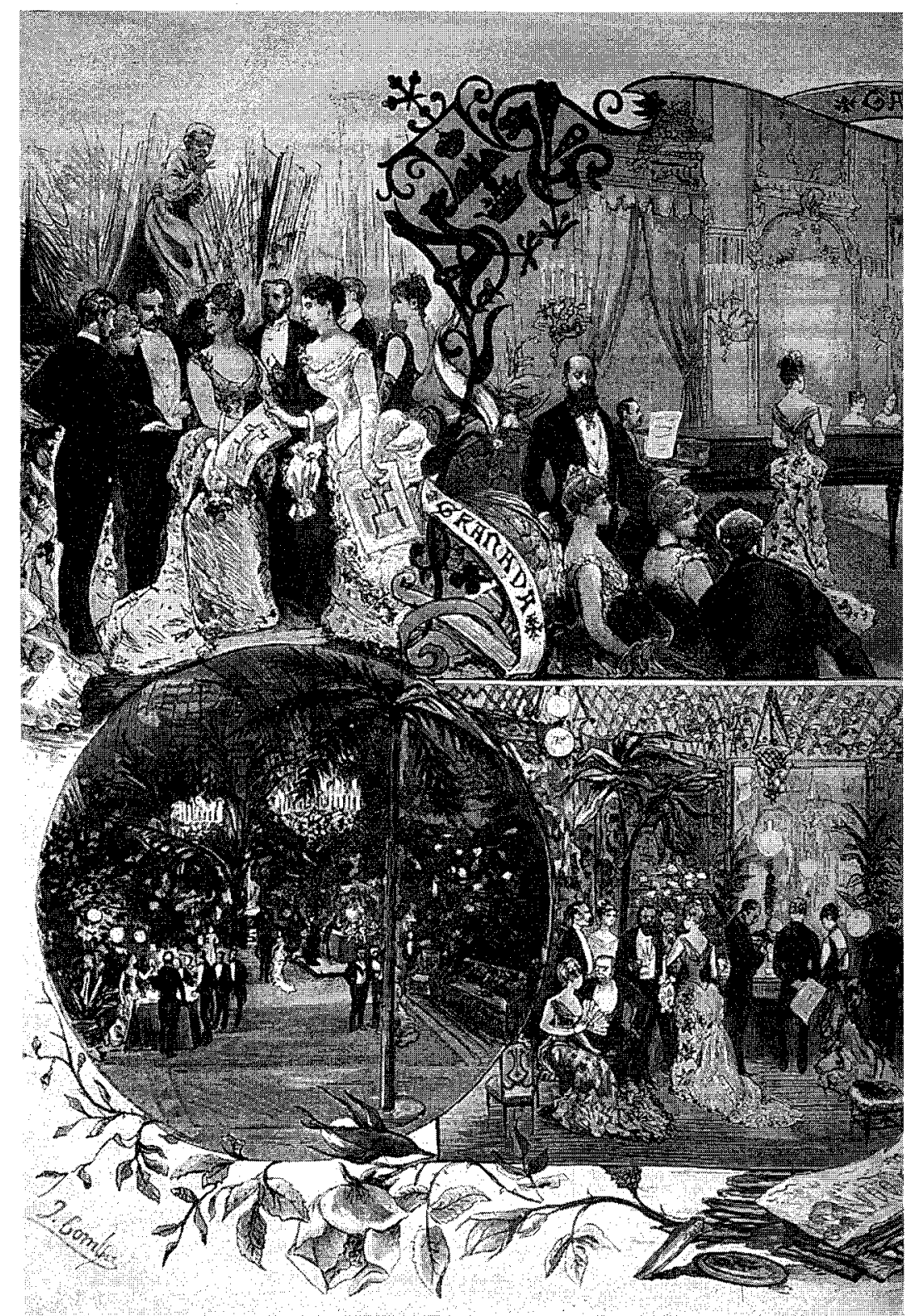

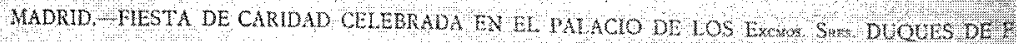

Fig. 3. Fiestas en el palacio de los Duques de Fernán-Nuñez.

(La llustración Española y Americana, 1885,1). Podemos observar cómo utilizaban las estufas para celebrar fiestas sociales. 
la evolución del jardín nobiliario en la España del siglo XIX, hay que considerar las diferentes fases de construcción de palacios: en torno a 1800 corresponde a la nobleza vieja, desde 1850 a la aristocracia del dinero, y con la restauración alfonsina la nueva burguesía ${ }^{54}$.

La zona periférica oriental de Madrid era el lugar donde se podía realizar la edificación aislada y el desarrollo de jardines; sin embargo, las dimensiones de los terrenos y solares distaba mucho, en la mayoría de los casos, de la amplitud que disfrutaban algunos de los palacios aristocráticos. La predilección por los jardines de tipo escenográfico pervivió en las quintas y villas suburbanas del Madrid isabelino, y no se dió en los nuevos palacios urbanos ${ }^{55}$.

En muchos de los nuevos palacios surgieron unos elementos muy importantes a partir de un momento en que la investigación e importación de las plantas y flores estaba muy en boga: los invernaderos. En el siglo XIX la horticultura sufrió un gran avance; importancia que hay que buscar en el exotismo de especies traídas de lugares tan distintos como son América, las Indias Orientales, Ceilán o Canarias ${ }^{56}$. Se escribieron numerosos libros sobre nuevas plantas, su aclimatación, etc...

Una de las consecuencias de ese desarrollo de la horticultura fue la proliferación de Jardines Botánicos, cuyo mayor impulso lo dio Carlos III. En poco tiempo ese gusto se trasladará a las clases más altas que querrían poseer el suyo propio, y que lo instalarán por lo general en su jardín. Así se empezaron a crear las llamadas "estufas" o invernaderos, con la idea de poder tener un ver perpetuum para rodearse de vegetación los doce meses del año. Eran una sutil transición entre la arquitectura y el jardín, y unían belleza y utilidad. Además, fusionaban los usos botánicos con los sociales, pues, eran un lugar de aclimatación de las plantas y escenario de fiestas y reuniones ${ }^{57}$. Estas construcciones eran un signo progresista y enriquecedor del propio jardín pues le proporcionaba especies nuevas y exóticas. Todas ellas debieron ser de un gran valor pues en todos los palacios que se preciasen debía haber una, o al menos, ese era el deseo de la mayoría de las personas que aspiraban a algo socialmente. Un ejemplo de ello lo encontramos en la figura de Obdulia, una de las

\footnotetext{
54 Navascués Palacio, P. Un palacio romántico. Madrid 1846-1858, ed. el Viso, Madrid, 1983, pág. 21.

55 Soto Caba, V. «Narciso Pascual y Colomer, el Marqués de Salamanca y los jardines madrileños del período isabelino», en El Palacio del Marqués de Salamanca, editado por la Fundación Argentaria, Madrid, 1994, pág.60.

${ }_{56}$ Algo que hemos visto en la descripción que hace Almudena de su tierra natal.

${ }_{57}$ La llustración Española y Americana, 1881, I parte, pág. 53.
} 
protagonistas de Misericordia, una joven que estaba obsesionada por las plantas, ya no sólo por lo que tenían de saludable, sino por su deseos de ascenso social, que eran alimentados por los relatos de su amigo Ponte Delgado, un aristócrata venido a menos, que le contaba lo maravillosos que eran los jardines y palacios de la alta sociedad. Obdulia le comenta a su amigo:

«No se puede imaginar cuánto me gustan las flores. Me muero por ellas. (...).Siempre que paso por un jardín, me quedo embobada mirándolas. (...) Yo sueño con tener un magnífico jardín y una estufa... ¡Ay! Esas estufas con plantas tropicales y flores rarísimas,...(...) ¿Pero no podría suceder que algún día tuviera yo una casa magnífica, elegante, con salones, con estufa... ${ }^{58}$.

La joven para emular el aspecto de estas construcciones, llenaba la casa de todo tipo de plantas y «puso la casa que daba gloria verla: los sucios pasillos se trocaron en vergeles, y la sala en risueño pensil» 59 ; y para su madre todo ello era maravilloso, y comentaba: “ ¡Benditas sean las flores - decía paseándose por sus encantados jardines- que dan alegría a las casas, bendito sea Dios, que nos permite disfrutar del campo, nos consiente, por poco dinero, que traigamos el campo a casa!" ${ }^{60}$. Y es que, como ya hemos visto anteriormente, estar rodeado de plantas era muy saludable. Las clases acomodadas tenían sus jardines y estufas, y en verano se marchaban al campo para descansar y huir del calor, mientras que las clases más humildes se limitaban a llenar sus casas de tiestos y a pasear por zonas ajardinadas.

Algo parecido a lo que ocurre en la casa de Obdulia podemos verlo en otras residencias como en la «mansión de Elias», en la calle Válgame Dios, que hacía las veces " de palacio. (...) ...los balcones del principal eran fiel remedo de los jardines colgantes de Babilonia..." ${ }^{61}$.

Pero volviendo a las verdaderas estufas que se construían los aristócratas, es interesante mencionar algo de la historia de este tipo de construcciones en nuestro país. Fernando VII cuando acometió la recuperación de la Casa de Campo, reparó varias de las edificaciones ya existentes, como es el caso de la Casa-palacio y el jardín que la rodeaba, donde mandó construir un estufa de madera y ladrillo. En 1805 mandó realizar un importante vivero con plantas traídas de Aranjuez. Más tarde,

\footnotetext{
Pérez Galdós, B. Misericordia, op. cit., págs. 170-1.

PÉrez Galdós, B. Ibidem, pág. 285.

Idem.

Pérez Galdós, B. La Fontana de Oro, Ed. Aguilar, Madrid, 1975, págs. 40-1.
} 
Paisaje de fondo o paisaje pleno: los paisajes y jardines del Madrid galdosiano

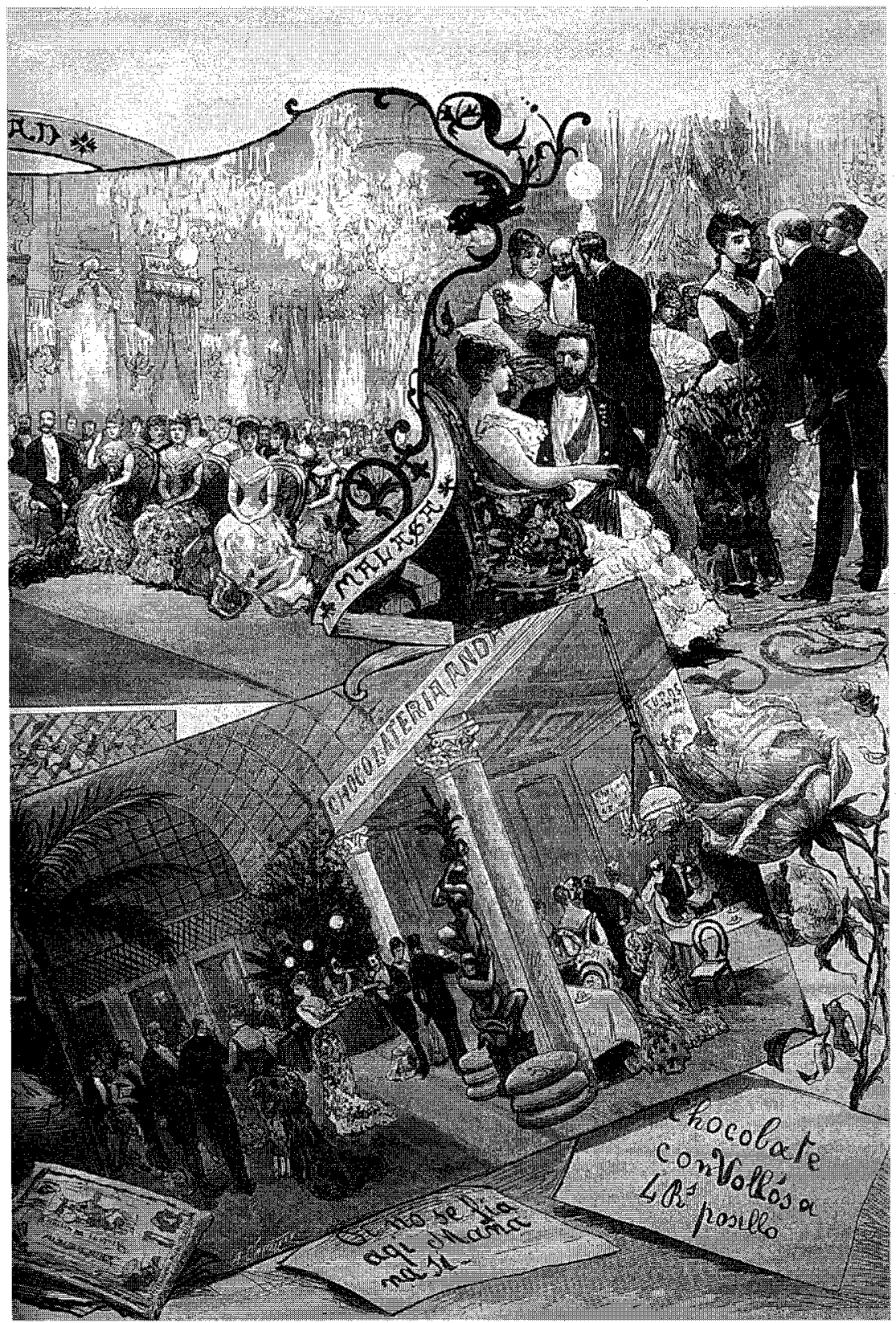

Fig. 4. Fiestas en el palacio de los Duques de Fernán-Núñez. (La ilustración Española y Americana, 1885, I). 
Isabel Il se ocupó de mejorarlo y continuó la obra de su padre en el Buen Retiro, y, además, durante su reinado se realizaron nuevas estufas, entre las que destacaban las que diseñó Narciso Pascual y Colomer en $1844{ }^{62}$. También dotó de invernaderos al nuevo parque del Palacio Real, el Campo del Moro: Naranjera o Estufa Grande o de las Camelias, estufa para Ananas, y estufa de conservación ${ }^{63}$.

Este tipo de construcciones eran muy costosas y por ello comenzaron a ser realizadas por la Corona, de ahí pasaron, tal vez por imitación, a las capas más altas de la sociedad. De hecho algunos de los numerosos hoteles que se construyeron en la prolongación de la calle Alcalá desde la Plaza de Cibeles tenían su bella estufa en su correspondiente jardín. Don Benito nos muestra algunos ejemplos de ello, y son en especial figuras femeninas las que desean tener este tipo de «caprichos». Uno de los ejemplos más claros es Pepita Fúcar, joven aristócrata y caprichosa, a la que le dice su amigo León:

«... tu padre, de tus caprichos hizo leyes (...). Hiciste construir una gran estufa en tu jardin, y una vez armada, la hiciste quitar de la fachada de Oriente para ponerla en la del Norte..." ${ }^{64}$.

O como en el caso de Eloisa Bueno cuando nos habla de la reforma de su palacio que consistía en poner a su patio una cubierta de cristales:

"...algo como la famosa estufa de Fernán Núñez ${ }^{65},(\ldots)$ la llenaría de plantas soberbias, latonias, rododendros, azaleas, araucanias, helechos arborescentes,... ${ }^{66}$.

El palacio de Fernán Núñez ${ }^{67}$ (que fue comisario del Retiro), se construyó de nueva planta en 1847 en el antiguo casco urbano, sobre la antigua huerta de recreo de Antonio Pérez, en la calle de Santa Isabel, y contaba con pequeño jardín geométrico y una estufa que debió ser muy conocida en la época.

\footnotetext{
62 Ariza Muñoz, C. «La Casa de Campo y el Buen Retiro: jardines madrileños que fueron del Real Patrimonio", en Reales Sitios, nº 85, 1985, págs. 65-69. Pág. 66.

${ }_{63}$ ARIZA MuÑoz, C. "Creación y mejoras de los jardines madrileños pertenecientes a la Corona», en Reales Sitios, no 88,1986 , págs. 29-36. Pág. 34.

${ }_{64}$ Pérez Galdós, B. La familia de León Roch, op. cit., pág. 792.

${ }_{65}$ En la llustración Española y Americana, 1884, I parte, pág. 165, aparece una estampa que refieja la fiesta y el baile que dieron los Duques de Fernán Núñez en su "serre". Cita tomada de Soto Caba, V. «Narciso Pascual y Colomer...», op. cit.. pág. 73, nota 28.

${ }_{6}$ Pérez Galdós, B. Lo prohibido, ob. cit., págs. 161-2.

${ }_{67}$ Sobre este palacio ver los dos artículos de Luz Buelga Lastra, "Casa mansión de los Duques de Albuquerque y Duques de Fernán Núñez", en la Revista Espacio, Tiempo y Forma, serie 7, tomos 5 y 6, UNED, Madrid, 1992 y 1993, págs. 395-424 y 491-532, respectivamente.
} 


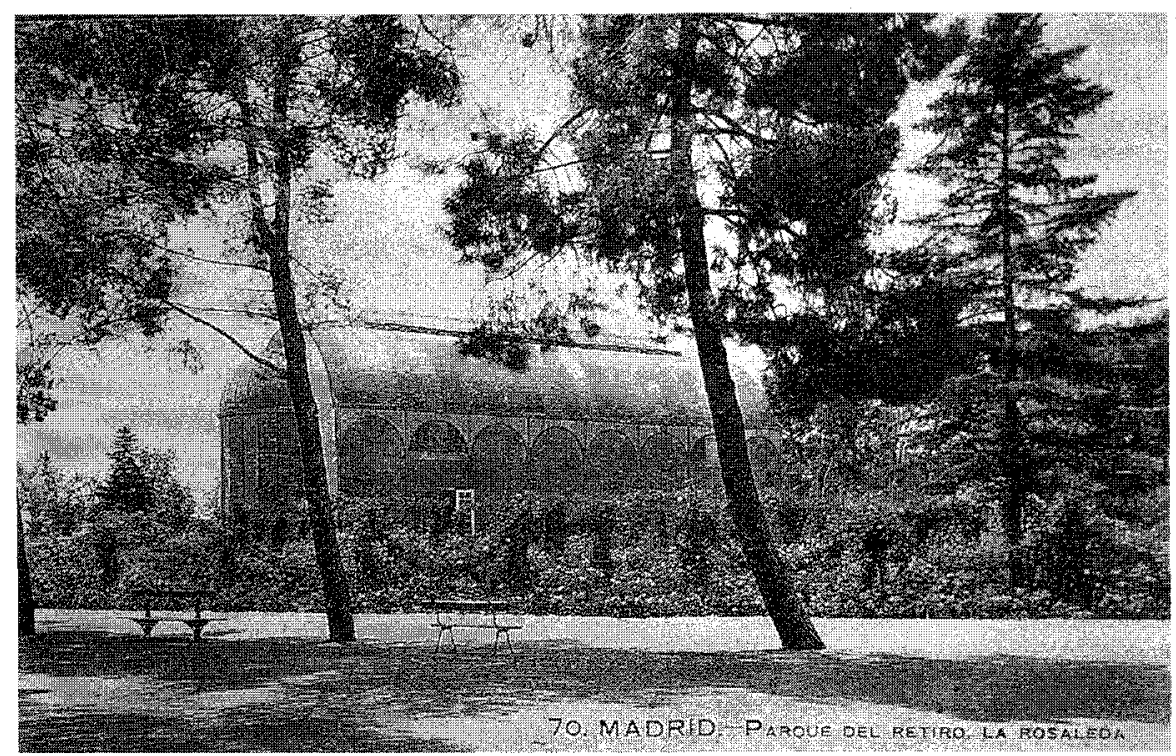

Fig. 5. Enorme estufa del jardín del Palacio del Marqués de Salamanca.

Pero la más conocida debió ser la del palacio del Marqués de Salamanca ${ }^{68}$, que fue levantada en el jardín posterior, y que fue cedida al Ayuntamiento de Madrid a cambio de terrenos, y se instaló en 1877 en el lugar que hoy ocupa La Rosaleda, donde permaneció hasta finales de los años veinte de nuestro siglo. Ponte Delgado, «que la conoció en sus buenos tiempos», se la describe a Obdulia:

«Figúresela usted más grande que esta casa y la de al lado juntas. Figúrese usted las palmeras y helechos de gran altura, y piñas de América con fruto. $\gg 6$.

Sin ninguna duda debió ser famosa por su frondosidad y riqueza. Al parecer el Marqués de Salamanca debió conocer en uno de sus viajes a París al Barón Rothchild, así como sus palacios, en uno de los cuales tenía un invernadero o «jardín de invierno» destinado al cultivo de especies tropicales ${ }^{70}$. Salamanca se sintió impresionado por su grandiosidad y

${ }_{68}$ Para más información sobre este palacio ver V.V.A.A.. El Palacio del Marqués de Salamanca, op. cit..

69 Pérez Galdós, B. Misericordia, op. cit., pág. 170-1.

70 Soto CABA, V. «Narciso Pascual Y Colomer...», op. cit., pág. 63. 
decidió hacer uno para sí. La planta de esta enorme estufa, que fue construida en los talleres de Londres en hierro y cristal, puede observarse en el plano de Madrid realizado por Ibánez lbero en 1872-74.

Don Benito hace alusión a otros palacios de nobles madrileños y sus jardines correspondientes, algunos de ellos de gran importancia histórica,como el jardín de Casa-Riera que se encuentra muy cerca de donde se asesinó a Prim; o como el Palacio de Liria, cuando Cadalsito, personaje de Miau, estaba viendo desfilar a los reclutas de Caballería y «se le fue la cabeza":

«... vi que la mole del cuartel se corría de derecha a izquierda, y que en la misma dirección iba el palacio de Liria, sepultado entre el ramaje de su jardín, cuyos árboles parecen estirarse para respirar mejor fuera de la tumba inmensa en que están plantados» ${ }^{71}$.

También menciona el viejo palacio de los Duques de Osuna ${ }^{72}$, cuando dice que Fernando Calpena llega -en tiempos de los enfrentamientos carlistas - a un palacio «tan viejo como suntuoso, que extiende sus amenos jardines no lejos de las Vistillas y de Nuestra Señora de la Almudena» ${ }^{73}$.

Los jardines de otros palacios nobles debieron ser muy considerados; así, por ejemplo, se compara el de la Alameda de Osuna ${ }^{74}$ con el Retiro por su frondosidad ${ }^{75}$. También hace referencia a los jardines del palacio de Medinaceli ${ }^{76}$, en la Plazuela de las Cortes $n^{\circ} 8$, que tenía un jardín geométrico y otro a la inglesa ${ }^{77}$; o al de Buenavista ${ }^{78}$.

Respecto a los hoteles y palacetes que se construyeron en la importante zona Alcalá-Prado-Recoletos, todos ellos con sus jardines, vemos como Alejandro, uno de los personajes de El Doctor Centeno, describe una de las zonas ajardinadas típicas de los mismos que se ve desde su habitación:

«...se dominaba toda la parte oriental de Madrid, que es la más hermosa (...) y detrás el árido campo donde pronto se habría de levantar el barrio de Salamanca (...). Era preciso mirar verticalmente (...) para alcanzar a ver

71 Pérez Galdós, B. Miau, ed. Hernando, Madrid, 1981, págs. 84-5.

72 Sobre estos jardines Véase Navascués Palacio, P. «Casas-Palacio de la Familia de Osuna" en el Catálogo de la exposición Jardines Clásicos Madrileños, Madrid, Museo Municipal, 1981, págs. 125-132.

${ }_{73}$ PÉrez Galdós, B. La Estafeta Romántica, Episodios Nacionales, Tercera Serie, nº 26, editorial Alianza-Hernando, Madrid, 1978, pág. 162.

${ }_{74}$ Pérez Galdós, B. Misericordia, op. cit., pág. 287.

75 Pérez Galdós, B. La Fontana de Oro, op. cit., págs. 11-12.

76 Idem.

77 MADOZ, P. op. cit. pág. 261.

78 Pérez Galdós, B. Fortunata y Jacinta, op. cit., pág. 175. 


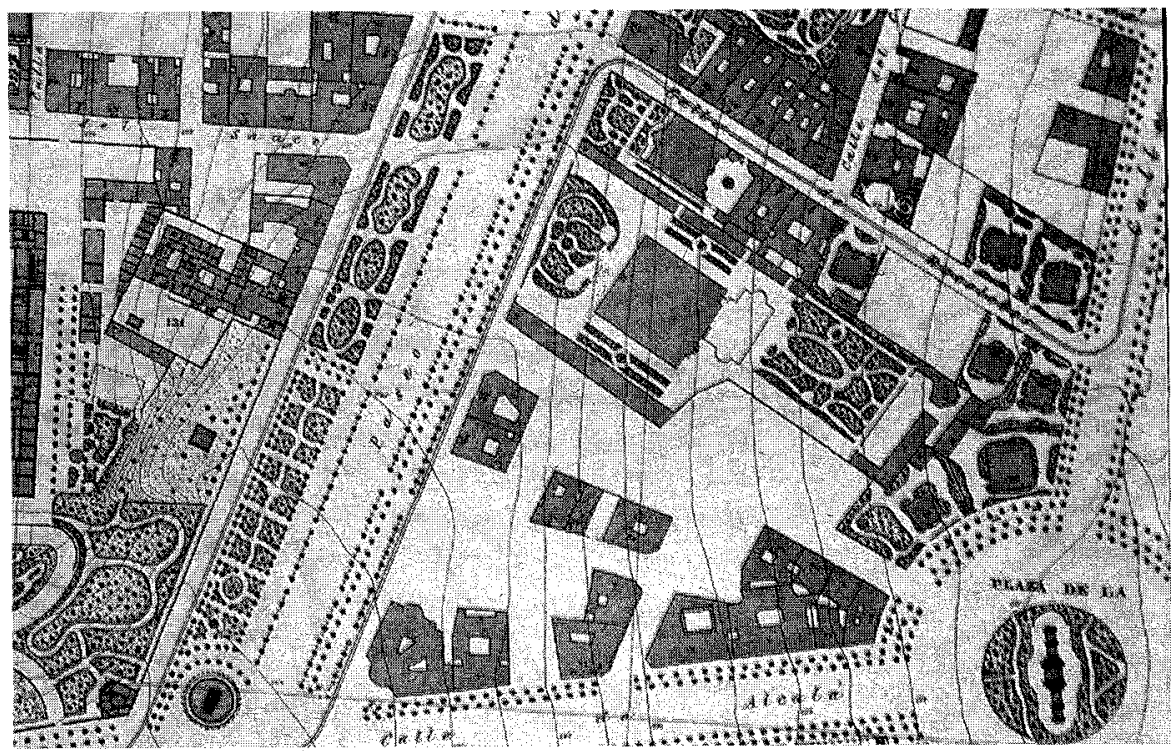

Fig. 6. Detalle del plano de Madrid de Ibáñez lbero, en el cruce de el Paseo de Recoletos con la calle Alcalá, y dónde podemos observar la enorme planta de la estufa del Marqués de Salamanca.

aquellos jardines (...). Pertenecían a lujosas casas de la calle del Prado, y estaban tan hondos que las ramas más altas de las acacias apenas llegaban al segundo piso. Con esmero y mimo cultivados, aquellos profundos vergeles se componian de afeitado césped, setos tijereteados, algunas coniferas y acacias, todo raquítico y achacoso (...). Los había varicosos, todos llenos de verrugas; los había reumáticos, mancos de ramas; habíalos atacados de alopecia, por lo cual tenían calvicie de hojas, y todos, calenturientos, revelaban en su amarillez el paludismo en que vivían. No faltaba tampoco una marmórea fuente..." ${ }^{79}$.

Estas «lujosas casas» pertenecían a gente adinerada procedente de la banca, el comercio, etc., que se afincó en esta nueva zona de la capital. Pero la descripción es un poco contradictoria, ya que habla de que son cuidados con «esmero y mimo», pero que están «raquíticos». En estas casas el modelo de jardín utilizado, a diferencia de los de las fincas de recreo y quintas, era el geométrico, y este fragmento lo pone aún más de manifiesto ya que habla de un «afeitado césped» y de «setos tijereteados»,

79 Pérez Galdós, B. El Doctor Centeno, ed. Aguilar, Obras Completas, Madrid, 1975, pág. 1.420 . 


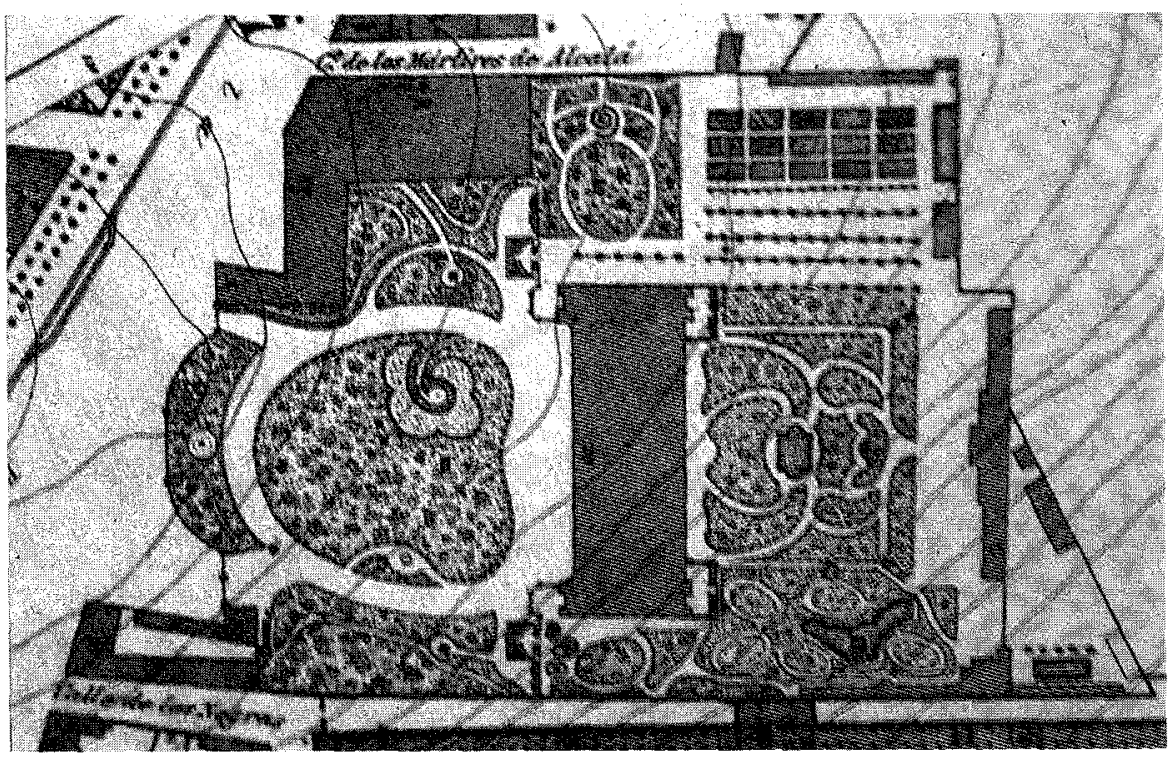

Fig. 7. Detalle del plano de lbáñez lbero en el que observamos la planta del jardín del palacio de Liria.

dos elementos del jardín geométrico o formal que no dejaba a la Naturaleza presentarse en su plenitud. Una vez más vemos como las clases que comienzan a ascender recurren a elementos distintivos de las antiguas clases dirigentes, mientras que éstas prefieren ahora otro tipo de diseño para los suyos, dentro de la tardía corriente paisajista o inglesa que apuesta por la libertad de las formas y que veremos más adelante.

De este modo nos encontramos en estos jardines de estos palacetes con una recuperación del jardín geométrico tradicional - dentro de la puesta en boga de los estilos historicistas en arquitectura, que puede observarse, por ejemplo, en los edificios del barrio de Retiro- que era la predominante, y cuya regularidad consistía en una traza típicamente francesa de cuatro parterres en torno a una fuente, y que a los ojos de Galdós eran ridículos, por lo reducido de su tamaño. Y es que la jardinería en la capital se encontraba con la dificultad añadida de la especulación del suelo, la aridez del terreno, así que los palacetes y hoteles, que no podian prescindir de un elemento de "glamour» como es el jardín, debían reducirlo a su mínima expresión.

Respecto a la importancia que tenían los jardines para estas viviendas de la alta sociedad del sector Prado-Recoletos-Castellana, don Benito recoge los pensamientos y recuerdos de un aristócrata ciego, perteneciente 


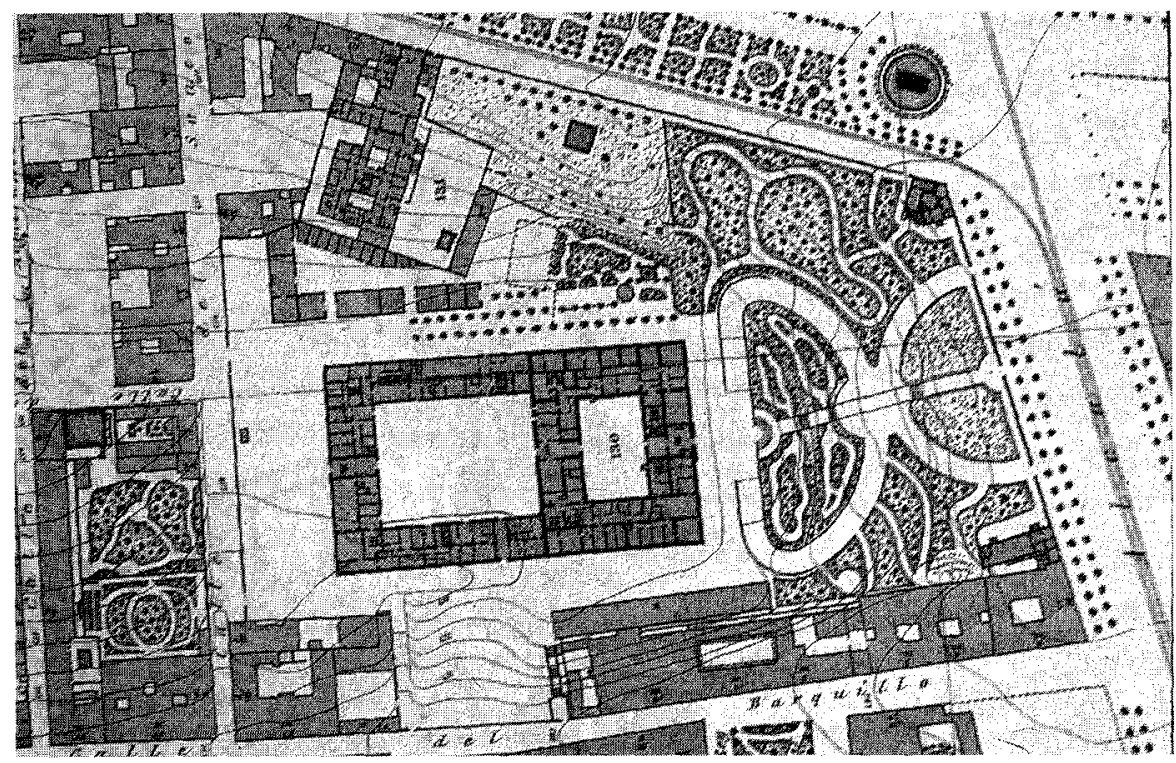

Fig. 8. Detalle del plario de lbáñez Ibero en el que observamos la planta del jardín del palacio de Buenavista.

a una familia venida a menos y que ha perdido su antiguo palacio, pero de él lo que más echa en falta es el jardín.

«...dirigiose a la Castellana por el andén de la derecha (...) respirando la delicia del aire tibio impregnado de emanaciones vegetales (...). "Paréceme que no me equivoco. El trecho recorrido desde la Plaza de Colón es la distancia exacta (...) estoy aquí frente al palacio donde vivimos en los tiempos de felicidad. Ahora viven aquí los Marqueses de Mejorada del Campo. Se me figura que poco han cambiado el hotel y el jardín. ¡Qué hermoso era antes!. ¡Qué precioso era el jardín de mi casa!... Y lo será todavia, (...) ¡Qué hermoso era el jardín y qué horas tan gratas he pasado en él»s ${ }^{80}$.

Y es que era en esos jardines donde se reunían y celebraban fiestas, en una palabra donde exhibían su condición de aristócratas, y allí acudía lo más selecto de la sociedad ${ }^{81}$. De hecho cuando un palacio como el de Gravelinas, entre las calles de San Bernardo y San Bernardino, tenía unos dueños de cierta relevancia social, pero no tenían amenos

so Pérez Galdós, B. Torquemada en la Cruz, Alianza, Madrid, 1979, págs. 217-19.

81 Pérez Galdós, B. Torquemada en el Purgatorio, Alianza, Madrid, 1979, pág. 256. 
jardines para disfrutar al encontrarse en la zona vieja de Madrid, la opinión general era la siguiente:

«...da carácter de triste población. Lo que allí falta son jardines, y muy de menos echaban este esparcimiento sus actuales poseedoras." ${ }^{82}$

Pero hay un aspecto muy interesante dentro de las viviendas de la alta sociedad. Me refiero a una zona situada en la periferia madrileña: los Carabancheles. En el siglo XIX, el Carabanchel Alto y el Bajo se fueron poblando de bellas y lujosas fincas de recreo, mandadas construir por las familias madrileñas acomodadas gracias a sus mejores condiciones paisajísticas y de accesibilidad a la capital. Allí pasaban las temporadas de descanso.

Nos encontramos ante uno de los mayores vacios documentales y cartográficos de la historia de la expansión de Madrid. Este lugar supuso un «pulmón adherido» ${ }^{83}$ a la ciudad por su posición despejada, y fue el sitio favorito de la sociedad de los años 40 del siglo pasado. Jardinería, vida social, vida cultural y activa son una misma cosa en los Carabancheles. La arquitectura carabanchelera es básicamente una arquitectura jardinera. Los jardines, que podrían clasificarse de expansivos, tenían múltiples elementos, y en ellas se unían los dos tipos de paisajes que diferencia Litvak: el utilitario y el ornamental ${ }^{84}$.

Esta arquitectura jardinera fue soporte ambiental de varias obras de Galdós -fue una zona activa de conflictos ideológicos y sociales-. Así, por ejemplo, vemos como Pedro Fúcar, el rico financiero de La familia de León Roch, tiene una finca deslumbrante, llamada Suertebella, situada en el Carabanchel Alto, cerca de la Vista-Alegre:

«...pasando el primer Carabanchel, León traspasó una verja de una magnífica finca, situada en el segundo Carabanchel o Alto. La posesión de Suertebella es una de éstas que el capital abundante y la paciencia han hecho en las proximidades de Madrid, y sostiene digna rivalidad con las célebres Vista-Alegre, Alameda de Osuna, Bedmar, en Canillejas. Tenía extenso y frondoso arbolado de olmos, acacias, gleditchias, sóforas, con su gran planicie de costoso césped, donde se vean gallardas sequoias, nísperos del Japón, magnolias y otras especies exóticas; magníficas estufas llenas de fuc-

B2 Pérez Galdós, B. Torquemada y San Pedro, Alianza, Madrid, 1979, págs. 489-90.

63 Grupo seminario sobre La imagen urbana. Cátedra de Proyectos II de la Escuela Técnica Superior de Arquitectura de Madrid. "Los jardines del Carabanchel», en el catálogo de la exposición Jardines clásicos madrileños, Ayuntamiento de Madrid, julio-agosto 1981, pág. 169.

${ }^{84}$ LiTVAK, L. El tiempo de los trenes. El paisaje español en el arte y la literatura del realismo, ediciones Serbal, Barcelona, 1991, pág. 100. 


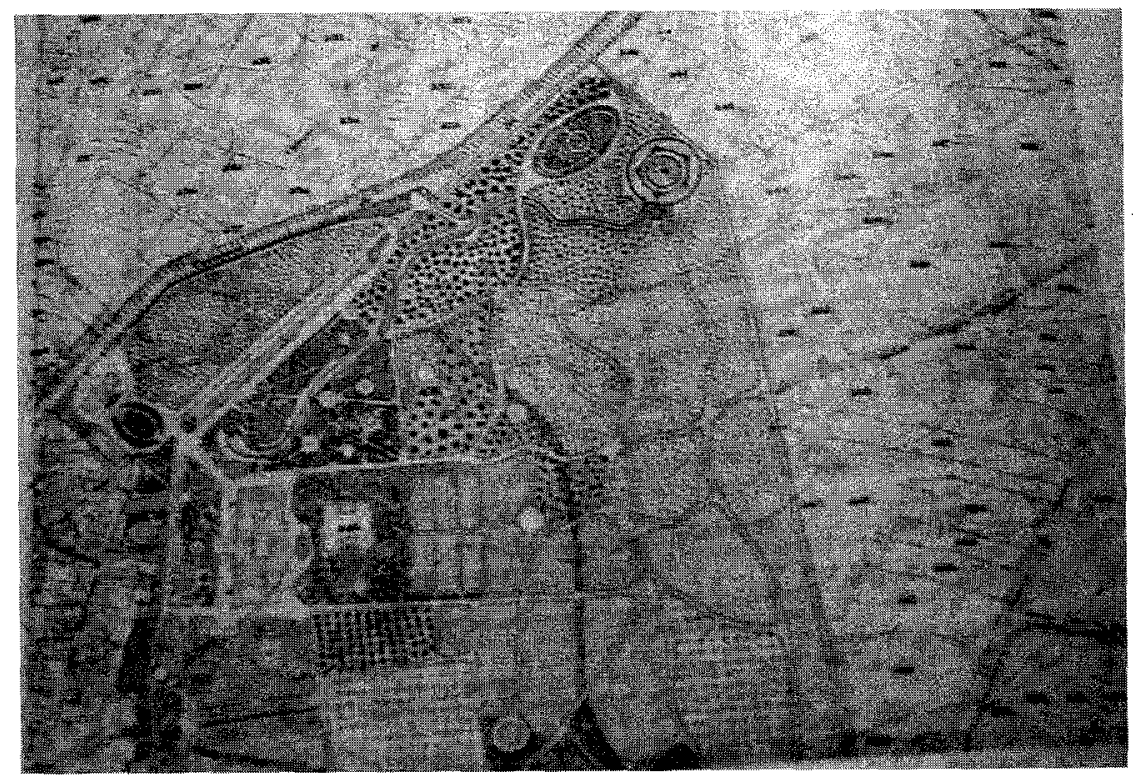

Fig. 9. Plano de la posesión de Vista-Alegre en el Carabanchel Bajo (1866).

sias y gomeros, helechos arborescentes, cactos y araucanas, corrales poblados de castas diferentes de gallináceas; cuadras donde los caballos vivían como caballeros, establos y pajarera, sin que faltase un poco de ría para pasear en barquichuelo, un tiro de pichón, gruta, estanquillo de piscicultura, hasta algo de ruinas con su imprescincible pincelada de yedra y musgo. ${ }^{85}$.

Tras esta descripción de Galdós y, consultando estudios específicos sobre esta zona madrileña, podemos llegar a la conclusión de que la finca de Pedro Fúcar es casi un retrato de lo que era Vista-Alegre: la parte del palacio, la estufa de la huerta, la estufa del jardín, una ría navegable, un dique, una codornicera, una faisanera, varias grutas, etc. ${ }^{86}$ Sin embargo, en el fragmento se habla de una cierta rivalidad entre Suertebella y VistaAlegre, pero algo que nos ayuda a pensar que Suertebella no existió en realidad ya que en las descripciones de la época en ninguna se habla de ella. Así, por ejemplo, por unos comentarios de Antonio Velasco ${ }^{87}$ sabemos

85 Pérez Galdós, B. La familia de León Roch, op. cit., págs. 854.

86 Grupo de seminario La imagen urbana, op. cit., págs. 172-3.

${ }_{87}$ Recogidos por Izquierdo, F. «Los Carabancheles", en Periferia de Madrid y pueblos de la Comunidad, Establecimientos Tradicionales Madrileños, Cuaderno VIII, Cámara de Comercio e Industria de Madrid, 1988, pág. 121. 
que se reunía lo más escogido de la sociedad, que estaba a cuatro kilómetros de Madrid, y que tenía una estupenda arboleda y unos jardines perfectamente cuidados, si bien Madoz consideraba que la más aventajada era la del Conde de Montijo ${ }^{8}$. Ello hace pensar en la posibilidad que antes he apuntado de que sean la misma finca, algo que toma más consistencia si añadimos que Pedro Fúcar puede ser una especie de contrafigura del Marqués de Salamanca, que adquirió Vista-Alegre en 1859 89: ambos son financieros, viven el eje Prado-Recoletos-Castellana, en sus palacios tienen una estufa, y poseen una finca en los Carabancheles (si bien uno en el Alto y otro en el Bajo).

Pero esta no es la única referencia a los jardines carabancheleros que hace nuestro escritor; en La España Trágica, vemos la descripción de otra de estas fincas, donde se encuentra la familia de los Ibero, y donde nos encontramos ante lo que Litvak clasifica de jardín naturalista, es decir, en el que la naturaleza vence sobre la obra del hombre ${ }^{90}$ :

«...la huerta había sido un jardín.(..) se veían señales de su noble abolengo. Testigo de la generación eran algunas matas de ciprés y boj recortados y otras lastimosas reliquias del estilo versallesco, pedruscos y trozos de cemento que habían sido gruta, y aún se conservaba una estatuilla descabezada (...). La traza del pensil había sido alterada para convertir los arriales floridos en tablones de hortalizas (...). Los padres (...) veía el ir y venir de la pareja por los senderos, ora curvos, ora rectos, de la plebeya finca descendiente de un aristocrático jardín... Se perdian a ratos tras un grupo de arbolillos, supervivientes de un lindo boscaje destruído, y reaparecían entre un cenador en ruinas... ${ }^{91}$.

Por esta descripción podemos comprobar que en aquellas fincas se mezclaba lo paisajista, que era el estilo dominante entre los aristócratas en este momento, y lo geométrico que Galdós llama «versallesco»; así como el paisaje cuidado de jardines, con la granja y el jardín productivo, donde se cultivaban "patatas, algarrobas,(...) calabacines, pepinos y zanahorias.» ${ }^{92}$. Y es que la vida campesina era una extravagancia de la que gustaban muchos nobles, por emular la antigua vida de los nobles en sus propiedades rurales de antaño ${ }^{93}$.

88 Ibidem, pág. 122.

89 ARIZA MuÑoz, C. "Creados por los Borbones. El Jardín Botánico, el Casino de la Reina y Vista-Alegre», en Reales Sitios, no 86, 1985, págs. 42-44. También de la misma autora, Jardines madrileños en el siglo XIX, ed. el Avapiés, 1988, págs. 96-101.

so LITVAK, L. Op. cit., pág. 108.

91 Pérez Galdós, B. La España Trágica, op. cit., págs. 17-8.

92 Ibidem, págs. 36-37.

93 Pérez Galdós, B. La Estafeta Romántica, op. cit., pág. 25 


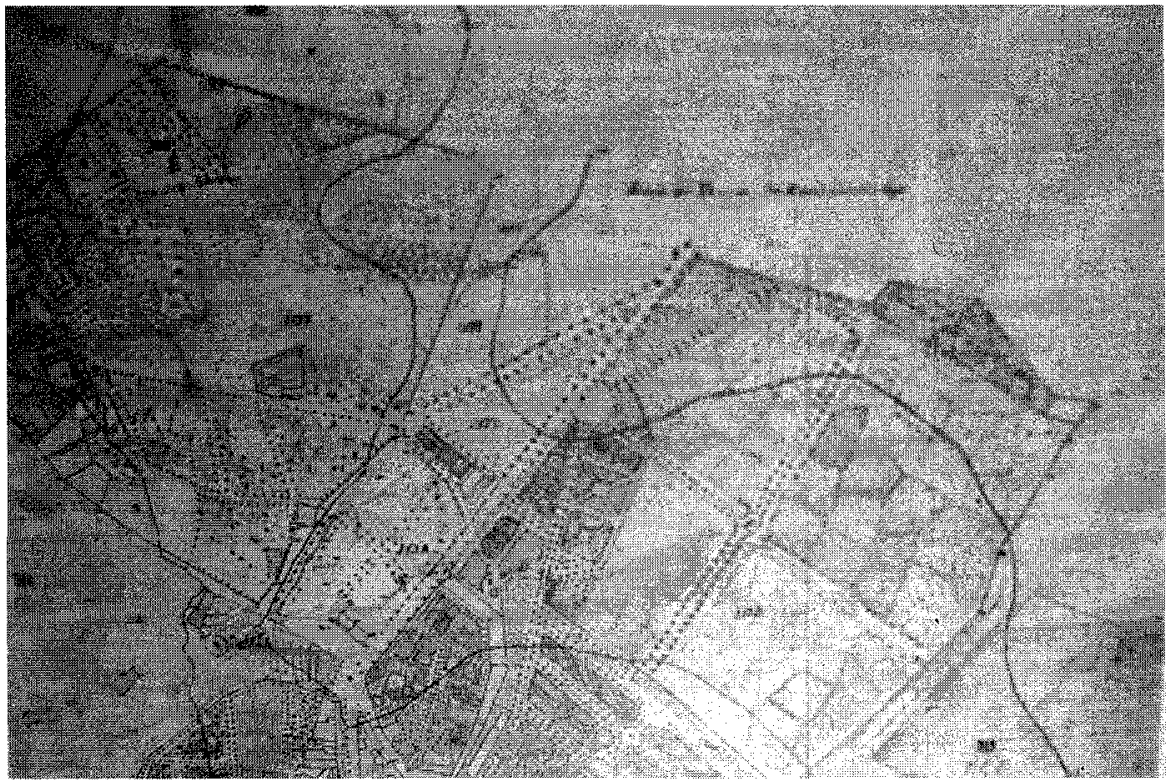

Fig. 10. Plano del Carabanchel Alto (1866), donde vemos en la finca 1132 las posesiones de la Condesa de Montijo.

En cuanto a los jardines privados de posesiones que han pertenecido a la Corona tenemos varios ejemplos además del ya comentado Retiro y la finca de Vista-Alegre. Por ejemplo, es interesante cómo se refiere a la Casa de Campo, Real Posesión que dejó de serlo con la instauración de la II República, y que aparece en pocas ocasiones en la obra galdosiana y muchas de ellas como simple referencia a los límites de la capital ${ }^{94}$. Pero en uno de los Episodios Nacionales se nos ofrece una descripción que tiene lugar en una cita amorosa, y se hace referencia a las mejoras ${ }^{95}$ que hizo el rey Fernando VII.

«-(...) Dicen que es un lugar muy bonito. Hay jardines preciosos y un lago (...) Pasearemos primero por entre árboles. (...).

Abandonando el coche avanzamos por las hermosas alamedas de aquel ameno sitio (...) Tal alameda no debía estar como la plantaron sus fundadores, (...) en determinados sitios debía de construirse un edificio, un pabellón,...(...)

94 Pérez Galdós, B. Miau, op. cit., pág. 404.

95 Para las mejoras de la Casa de Campo ver ARIZA MuÑoz, C. «La Casa de Campo y el Buen Retiro, jardines que fueron del Real Patrimonio", en Reales Sitios, $n^{\circ}$ 85, 1985, págs. 65-72. 
Presentacioncita se extasiaba en la contemplación del Lago, que es el principal adorno y riqueza de la hermosa finca" ${ }^{96}$.

También menciona nuestro escritor el Parque de Palacio, o Campo del Moro, que no nació como jardín hasta el reinado de Isabel II, en un principio el diseño era de unos paterres geométricos cruzados por una gran avenida en dirección E-O, atravesada por otra N-S. Se trajeron materiales de otros Reales Sitios, como las fuentes principales: la de los Tritones y la Concha ${ }^{97}$. Tratándose del jardín del Palacio Real es lógico que se aluda a él en La de Bringas, ya que Bringas tenía en su taller un ventana que daba al Campo del Moro, porque la familia vivía en el segundo piso, igual que el resto de los empleados ${ }^{98}$. También alude a la «verdura del Parque» y a «la escalera de piedra» que baja hasta él en otro de los Episodios Nacionales ${ }^{99}$.

Pero una de las descripciones más bellas que hace don Benito de un Real Sitio es la del Casino de la Reina que encontramos en Tormentas del 48:

«...un Sitio Real chiquito, al fin de la calle de Embajadores, con un jardín muy hermoso y un poco de templete y un poco de palacio;(...), venturoso rincón del Paraíso terrenal.

- No vaya usted a creer que es un Versalles, ni un Pincio, ni un Aranjuez.(...)

Corrí por un curvo caminillo, (...). Después de divagar solos por aquella ondulada amenidad, llevome la dama a un templete, erigido entre verdosos estanquillos. Era de piedra y mármoles, semejante a los que hay en Aranjuez, pero de juguete, abierto por tres costados de su rectangular arquitectura, y decorado con bichas y quimeras al fresco, un poco deslucidas por la humedad, todo en el estilo neoimperial de Fernando VII...” ${ }^{100}$.

Este Real Sitio tiene su origen en la donación que hizo el Ayuntamiento de Madrid, en 1817, a la reina Isabel de Braganza por su segundo embarazo. En sus jardines se mezclaban el trazado paisajista con el regular, también había fuentes, estanques, pero destacaba sobre todo la ría, con puentes, etc ${ }^{101}$.

${ }_{96}$ Pérez Galdós, B. Memorias de un cortesano de 1815, Episodios Nacionales, Serie Segunda, $n^{\mathrm{o}}$ 13, Ed. $\mathrm{H}^{\mathrm{a}}$ 16-Altorrey, Madrid, 1993, págs. 171-180.

${ }_{97}$ ARIza MuÑoz, C. Jardines madrileños..., op. cit., págs .101-112.

98 PÉrez Galdós, B. La de Bringas, op. cit., pág. 64.

99 Pérez Galdós, B. Siete de Julio, Episodios Nacionales, Serie Segunda, nº 15, págs. $130-1$.

100 Pérez Galdós, B. Tormenta del 48, Episodios Nacionales, Serie Cuarta, n 31 , Ed. $H^{\mathrm{a}}$ 16-Caja Madrid, Madrid, 1995, págs. 191-97.

${ }_{101}$ Para el Casino de la Reina ver ARIZA, C. «La jardinería de los Reales Sitios en el Madrid fernandino», op. cit.; “El Jardín Botánico, el Casino de la Reina y Vista-Alegre...», op. cit. 


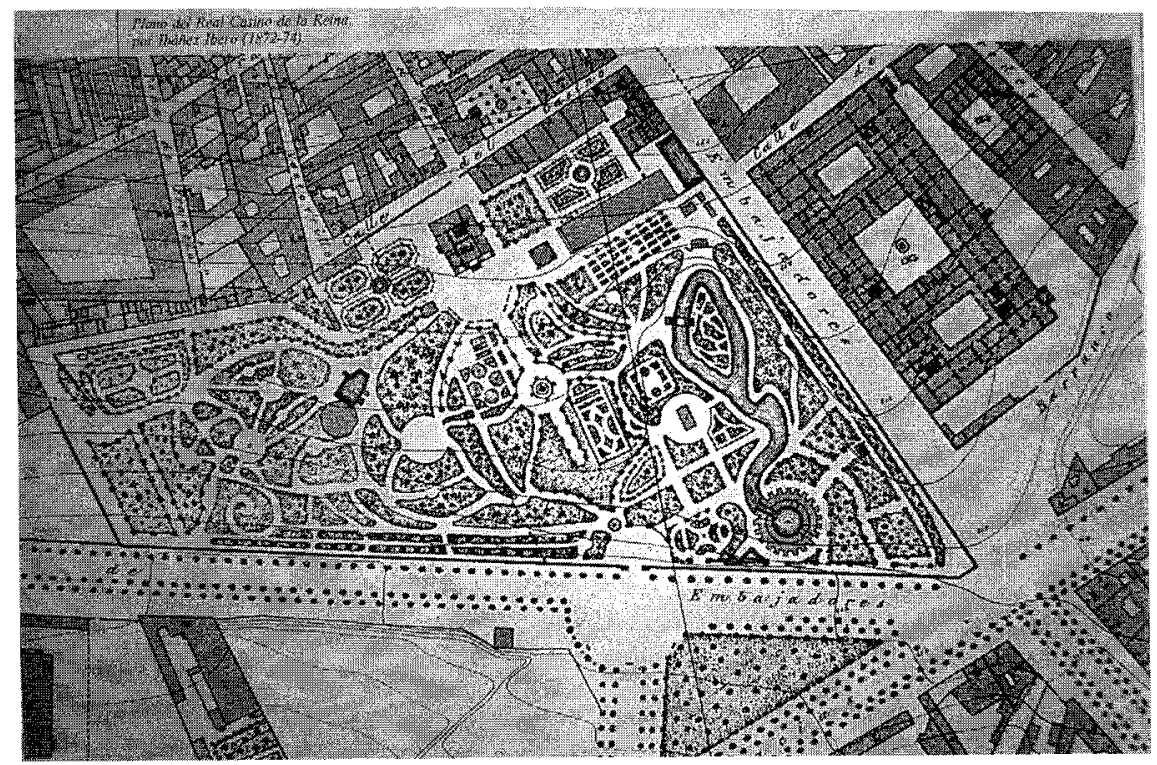

Fig. 11. Plano de los jardines del Casino de la Reina.

Con esta sucesión de citas podemos crearnos una idea de los diversos aspectos de los paisajes y jardines - tanto públicos como privados- del Madrid del siglo pasado, según la aguda mirada de don Benito Pérez Galdós, que recoge los diferentes valores sociales de los mismos. Se recalca así la idea del entorno rico, ameno y amable que prefieren las clases más acomodadas, acudiendo en ocasiones a ciertos lugares para «ver y dejarse ver», frente a los áridos y tristes parajes en los que aparecen los personajes de los estratos más humildes de la sociedad. 
